\title{
Studies in Iron Manufacture Technology through Analysis of Iron Artifact in Han River Basin during the Proto-Three Kingdoms
}

\author{
Soo-Ki Kim \\ Department of Cultural Heritage, Yongin University, Yongin 449-714, Korea
}

Manuscript received 11 October 2012; revised 6 November 2012; accepted 13 November 2012

(c) The Korean Society of Conservation Science for Cultural Heritage 2012

\begin{abstract}
The most widely excavated iron artifacts used as weapons or farm tools from central southern regions of Korea were subjects of non-metallic inclusion analysis through metallographic examination, microhardness measurement, and scanning electron microscopy with energy dispersive X-ray spectroscopy. Through metallographic interpretation and study of the analyzed results, the steel manufacturing and iron smelting using heat processing in the iron artifacts excavated from the central southern region of the ancient Korean peninsula was studied, and the analysis of the non-metallic inclusions mixed within the metallic structures was interpreted as the ternary phase diagram of the oxide to infer the type of iron ores for the iron products and the temperature of the furnace used to smelt them. Most of the ancient forged iron artifacts showed $\mathrm{Al}_{2} \mathrm{O}_{3} / \mathrm{SiO}_{2}$ with high $\mathrm{SiO}_{2}$ contents and relatively low $\mathrm{Al}_{2} \mathrm{O}_{3}$ contents for iron ore, indicating that for $\mathrm{Al}_{2} \mathrm{O}_{3}$ below $5 \%$, it is presumed that magnetic iron ores were reduced to bloom iron (sponge iron) with direct-reduction process for production. The temperature for extraction of wustite for $\mathrm{Al}_{2} \mathrm{O}_{3}$ below $1 \%$ was found to be $1,020 \sim 1,05$ $0{ }^{\circ} \mathrm{C}$. Considering the oxide ternary constitutional diagram of glassy inclusions, the steel-manufacturing temperature was presumed to have been near $1,150 \sim 1,280^{\circ} \mathrm{C}$ in most cases, and minimum melting temperature of casting iron part excavated in Daeseong-ri. Gyeonggi was near $1,400^{\circ} \mathrm{C}$, and it is thought that hypoeutectic cast iron of about $2.3 \%$ carbon was casted and fragility of cast iron was improved by decarburizing in solid state.
\end{abstract}

Key words: Iron artifact, Iron ore, Heat treatment, Non-metallic inclusions, Ternary phase diagram of the oxide

\section{INTRODUCTION}

Archaeologically, there are many theories on iron artifact of the Korean Peninsula but it is a common theory that it had started to be brought from north in around the fourth century BC, to Han River basin in the third century BC and to Nakdong River area in the south in around the first century BC (Kim, 1986). Considering the fact that wrought iron and cast iron were produced as in the iron manufacture technology in China, it is known that the iron had been introduced into the Korean Peninsula through the mass migration of the group who developed iron manufacture technology in China.

Corresponding author: Soo-Ki Kim

E-mail: skkim@yongin.ac.kr
In addition, it is the prevalent view of archaeologists or historians that the Korean Peninsula accepted iron manufacture technology from China, developed it in their way and spread it to Japan.

In this study, microstructure was investigated targeted at iron artifacts of Proto-Three Kingdoms that had been excavated from Han River basin and metallographic interpretation and research have been done on steel manufacture and manufacturing technology that uses heat treatment of iron artifacts excavated through an analysis of microhardness measurement and nonmetallic inclusions. And also, I tried to study the temperature of iron manufacture.

Also, I tried to study the temperature of iron manufacture in which materials for iron artifacts was smelted by reinterpreting the analyzed non-metallic inclusions in microstructure to ternary phase diagram. By doing so, I tried to study steel manufacture, iron artifact and manufacturing technology through iron manufacturing technology and heat treatment in Han River basin where the politics and economy was developed and there were a lot of exchanges with other regions with Han River as the center as the central zone in Proto-Three Kingdoms.

\section{IRON OBJECTS FOR STUDY}

In this study, the iron artifacts in Table 1 that were excavated from 3 sites in Yeongjong-do in Incheon, Garak-dong in Seoul, Daesung-ri in Gapyeong, near the Han River basin in 3-4 century, archaeologically the Proto-Three Kingdoms, are targeted.

Table 1 classified sites, indicated the quantity and EDS analysis of the targeted artifacts of each site as well as collected specimen, and compared the types of artifacts by categorizing the purpose of artifacts and use.

\section{ANALYTICAL METHOD}

\subsection{Microstructure investigation}

In general, it requires careful attention to collect metal that is 
not etched from ancient iron artifacts as specimen. That is because collecting part of metal artifacts of cultural properties that have cultural and historical values, not just an object of study, damages them even if the purpose was for research. Therefore, researchers who collect specimen from ancient iron artifacts must collect specimen within a range of minimum damage they would cause on the appearance of artifacts with strict ethical values.

In this study, I collected specimen from where magnetite layers are exfoliated in the process of conservation or took an X-ray of iron artifacts for artifacts that are not exfoliated in order to check where metal leads are left, to take out the magnetite layers, etching layers of the surface, and collected specimen and did an adhesive restoration to avoid damage on the original form of artifacts as much as possible.

I executed cold mounting, grinding and polishing the specimen as epoxy resin to observe and analyze microstructure, and observed it by etching it at nital 3-10\% for a few seconds. Then, I measured Vickers hardness and took pictures of microstructure by magnifying the metallographic microscope by 50-500 times larger.

\subsection{Analysis and interpretation of nonmetallic inclusions}

In this study, microstructure of specimen was observed through metallographic microscope, nonmetallic inclusions in the specimen were partially magnified and observed by Scanning Electron Microscopy (SEM) and Energy Dispersive Spectrometer (EDS) that is attached on SEM was used to analyze its constituents. Current data analyzed in element were converted to oxide by using oxide calculation for study of oxide phase diagram.

In smelting process, part of impure elements are remitted as gas after oxidation but most of them are separated from the smelted iron as an oxide and make flexible smelted iron by adding proper flux. The smelted iron removes pernicious ingredients such as P, S, keeps beneficial elements such as Fe and others from loss and retains oxidized steel as a medium to carry oxygen. Also it prevents contamination of oxygen or gas from the atmosphere.

Table 1. Type and specimen of research object site and artifact.

\begin{tabular}{|c|c|c|c|c|c|c|}
\hline $\begin{array}{l}\text { Name of } \\
\text { Region }\end{array}$ & Name of Site & Name of Artifact & $\begin{array}{l}\text { Number of } \\
\text { Specimen }\end{array}$ & $\begin{array}{c}\text { Number of } \\
\text { Analysis }\end{array}$ & Type & Era \\
\hline \multirow{10}{*}{$\begin{array}{c}\text { Han River } \\
\text { Basin }\end{array}$} & \multirow{4}{*}{$\begin{array}{c}\text { Daesung-ri, } \\
\text { Gapyeong }\end{array}$} & Iron Axe & 2 & 1 & Farming Related Tool & \multirow{4}{*}{$3 \mathrm{C}$} \\
\hline & & Iron Sword & 1 & - & Weapon & \\
\hline & & Iron Arrowhead & 2 & 1 & Weapon & \\
\hline & & Iron Artifact & 2 & 2 & Etc & \\
\hline & \multirow{2}{*}{$\begin{array}{l}\text { Yeongjong-do, } \\
\text { Incheon }\end{array}$} & Iron Chisel & 1 & 1 & Craftsman Tool & \multirow{2}{*}{$4 \mathrm{C}$} \\
\hline & & Iron Sickle & 1 & 1 & Craftsman Tool & \\
\hline & \multirow{4}{*}{$\begin{array}{l}\text { Garak-dong, } \\
\text { Seoul }\end{array}$} & Nail & 2 & 1 & Etc & \multirow{4}{*}{$4 \mathrm{C}$} \\
\hline & & Clamp & 3 & 3 & Etc & \\
\hline & & Iron Spear & 1 & 1 & Weapon & \\
\hline & & Iron Knife & 1 & 1 & Craftsman Tool & \\
\hline
\end{tabular}
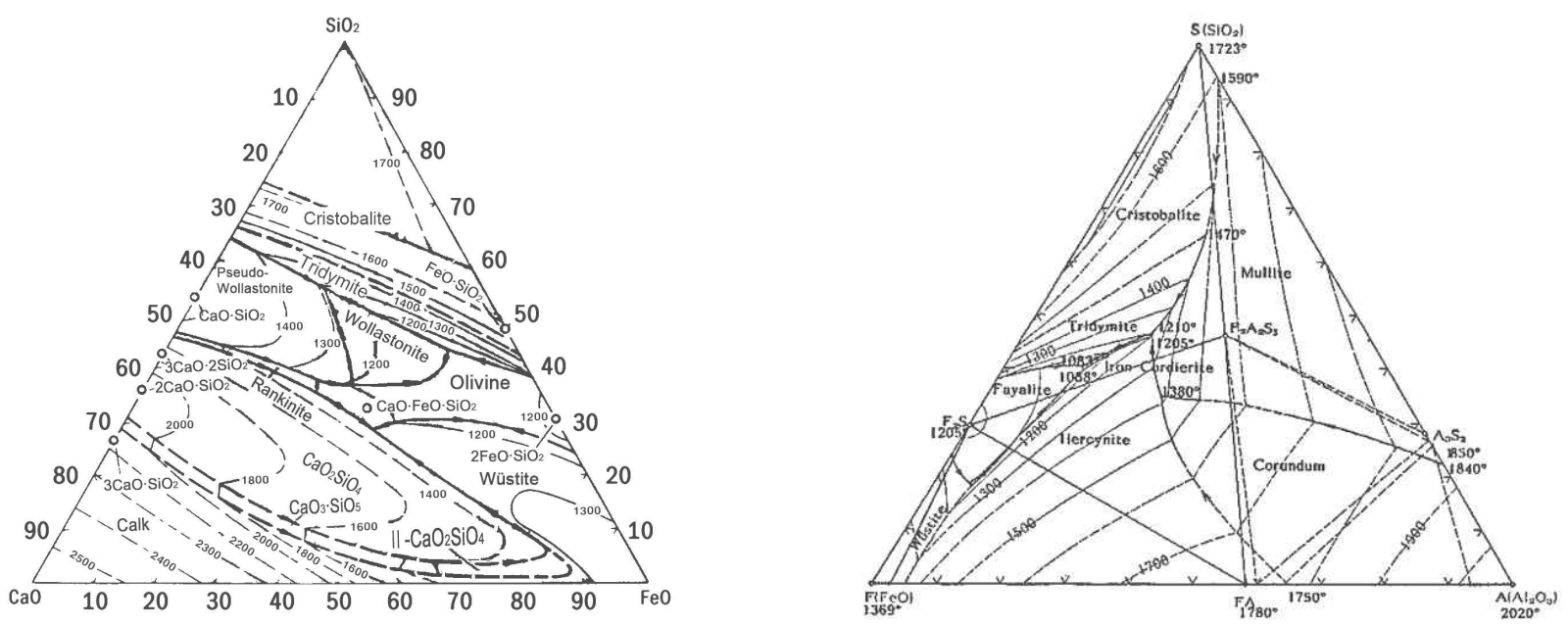

Figure 1. $\mathrm{FeO}-\mathrm{CaO}-\mathrm{SiO}_{2}$ (left) and $\mathrm{FeO}-\mathrm{Al}_{2} \mathrm{O}_{3}-\mathrm{SiO}_{2}$ (right) phase diagrams (Engell, 1991; Lee et al., 2001). 
In order to have such functions, iron should have proper composition and viscosity. Composition of iron depends on the method of work and raw material of iron manufacture, steel manufacture or type of flux and wall furnace, and $\mathrm{FeO}-\mathrm{CaO}-$ $(\mathrm{MgO})-\mathrm{SiO}_{2}$ is the main constituent in basic process and FeO-MnO- ( $\mathrm{MgO})-\mathrm{SiO}_{2}$ in acid process. It is possible to assume the temperature of the furnace by substituting the analyzed data with $\mathrm{FeO}-\mathrm{CaO}-\mathrm{SiO}_{2}$ (FCS) constitutional diagram in and $\mathrm{FeO}-\mathrm{Al}_{2} \mathrm{O}_{3}-\mathrm{SiO}_{2}$ (FAS) constitutional diagram in Figure 1 considering the fayalite $\left(\mathrm{Fe}_{2} \mathrm{SiO}_{4}\right)$ slag case of ancient iron manufacturing furnace where the smelting temperature was low in the proper slag area as the main constituent of excavated slag from ancient iron manufacturing furnace is $\mathrm{FeO}, \mathrm{CaO}, \mathrm{SiO}_{2}$, $\mathrm{Al}_{2} \mathrm{O}_{3}$. In Figure 1 of FCS, it is known that as compounds of calcium, $\mathrm{CaO}$ lowers viscosity of oxide with high viscosity such as $\mathrm{SiO}_{2}, \mathrm{Al}_{2} \mathrm{O}_{3}$ of slag, and as a flux that increases fluidity of it so that slag can be effused well, it has been working since the ancient times by charging into furnace along with ore. This FCS elementary system is the main oxide in nonmetallic inclusions and as $\mathrm{Al}_{2} \mathrm{O}_{3}$, neutral oxide, plays an important role in slag, we can assume the temperature of furnace from nonmetallic inclusions that have low $\mathrm{Al}_{2} \mathrm{O}_{3}$ or no $\mathrm{Al}_{2} \mathrm{O}_{3}$. In addition, in case of now $\mathrm{CaO}$ or no $\mathrm{CaO}$ in nonmetallic inclusions, the temperature of furnace can be assumed through FAS constitutional diagram

Table 2. Result of analysis on SEM-EDS in Figure 2D (wt \%) and temperature of ternary phase diagram $\left({ }^{\circ} \mathrm{C}\right)$.

\begin{tabular}{cccccccc|cc}
\hline Point & $\mathrm{MgO}$ & $\mathrm{Al}_{2} \mathrm{O}_{3}$ & $\mathrm{SiO}_{2}$ & $\mathrm{P}_{2} \mathrm{O}_{5}$ & $\mathrm{~K}_{2} \mathrm{O}$ & $\mathrm{CaO}$ & $\mathrm{FeO}$ & $\mathrm{FAS}$ & FCS \\
\hline $\mathrm{a}$ & - & 13.20 & 17.20 & 12.87 & 2.47 & 14.50 & 39.77 & 1,200 & 1,240 \\
\hline
\end{tabular}
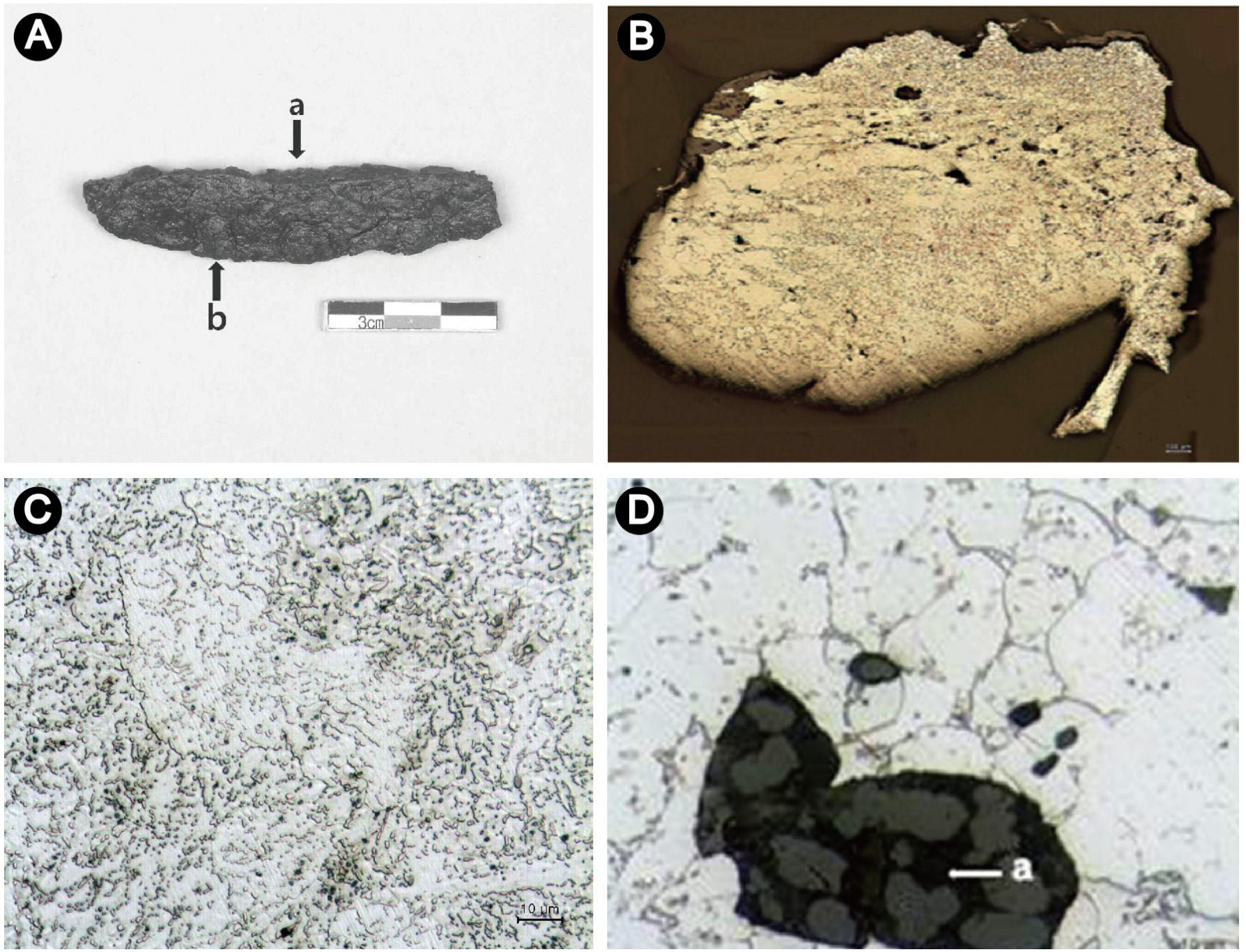

Figure 2. Microstructure and analysis of iron artifact excavated from the $2^{\text {nd }}$ site of house in Daesung-ri site (Yang and Kim, 2011). (A) Sampling position. (B) Overall view of microstructure. (C) Spheroidal cementite. (D) The SEM image of the iron artifact of $2^{\text {nd }}$ site of house. 
in Figure 1.

I normalized by $100 \%$ three oxides that consist of ternary phase diagram in order to substitute with nonmetallic oxide in ancient iron artifacts, FCS and FAS constitutional diagrams show different temperatures even in the same slag due to the difference in composition. In such case of singular slag such as glassy, the main components of two constitutional diagrams were used to assume temperature. The temperature of singular glassy slag was assumed as the maximum smelting temperature at the time of smelting.

\section{RESULT AND CONSIDERATION}

\subsection{Iron objects from Daesung-ri, Gapyeong}

In Daesung-ri site in Gapyeong, an iron artifact, iron arrowhead, iron knife, casting and iron axe that were produced by forging in the site of house were excavated. The microstructure of artifacts varies a little but as the overheatered structure of hypo-eutectoid steel that has low carbon seems to have been formed, I studied the structure and analysis on the iron artifact of $2^{\text {nd }}$ site of house and casting iron axe as a representative (Yang and Kim, 2011).

Table 3. Analysis result of SEM-EDS in Figure 3D (wt\%) and temperature of ternary phase diagram $\left({ }^{\circ} \mathrm{C}\right)$.

\begin{tabular}{ccccccccc|cc}
\hline Point & $\mathrm{MgO}$ & $\mathrm{Al}_{2} \mathrm{O}_{3}$ & $\mathrm{SiO}_{2}$ & $\mathrm{P}_{2} \mathrm{O}_{5}$ & $\mathrm{~K}_{2} \mathrm{O}$ & $\mathrm{CaO}$ & $\mathrm{MnO}$ & $\mathrm{FeO}$ & $\mathrm{FAS}$ & FCS \\
\hline $\mathrm{a}$ & 2.16 & 4.34 & 22.71 & 9.41 & 2.07 & 3.40 & 2.69 & 53.23 & 1,390 & 1,180 \\
\hline
\end{tabular}
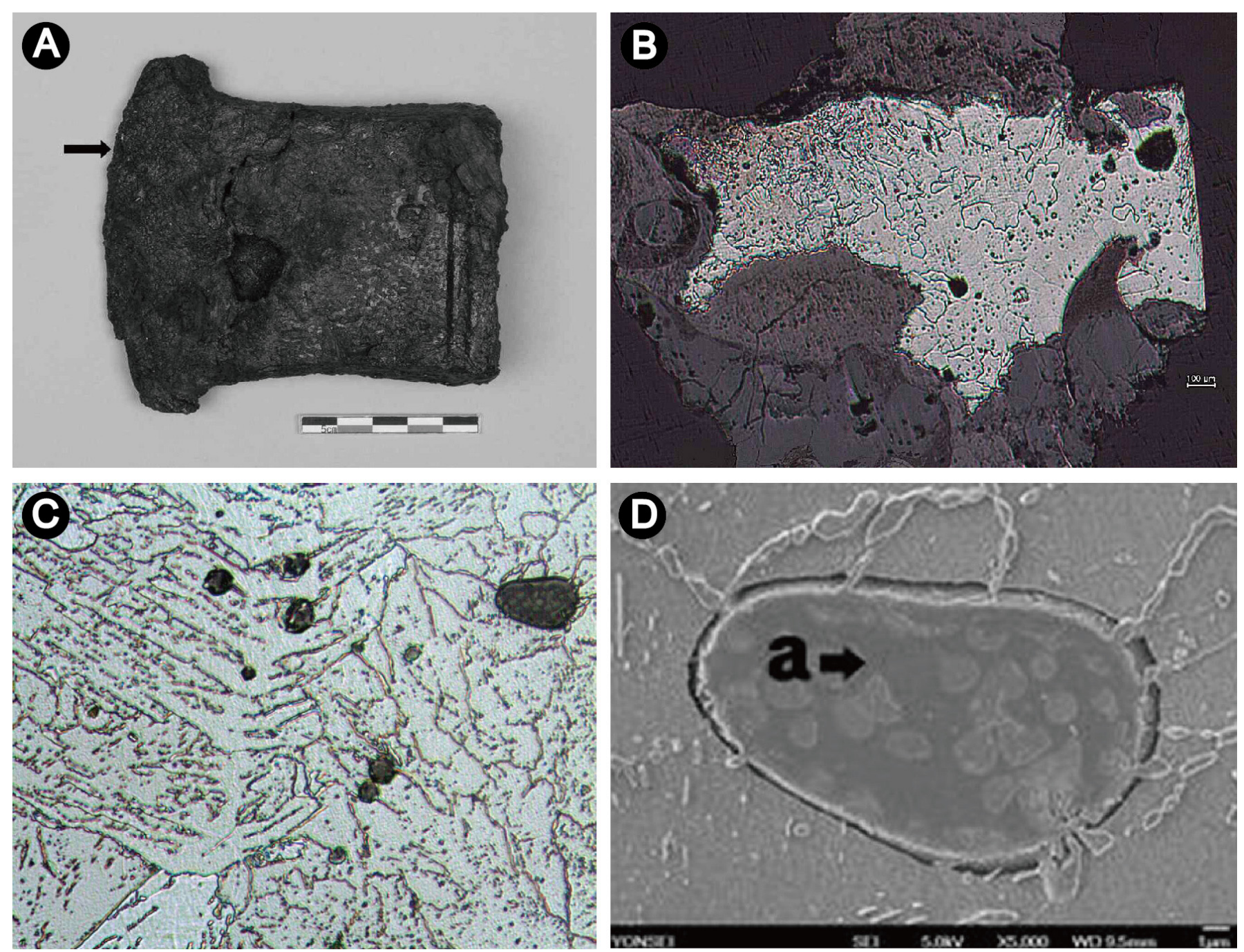

Figure 3. Microstructure and analysis of iron axe excavated from the $10^{\text {th }}$ site of house in Daesung-ri site (Yang and Kim, 2011). (A) Sampling position. (B) Overall view of microstructure of sample. (C) Decarburized hole and Widmanstätten. (D) The SEM image of nonmetallic inclusion of $(\mathrm{C})$. 
I collected and observed the specimen from the same point as Figure $2 \mathrm{~A}$ in order to analyze the structure of iron artifact excavated from the $2^{\text {nd }}$ site of house in Daesung-ri. Both $a$ and $b$ show similar structure overall, and ferrite, the rough pure iron structure of below $0.05 \% \mathrm{C}$ in a part as in Figure 2B, is randomly distributed, and converted structure from cementite in layer pearlite which is formed after heat treatment at low temperature than eutectoid temperature as in Figure $2 \mathrm{C}$, is observed. In addition, fine nonmetallic inclusions of different sizes are located in between structures and some of them are concentrated in some part.

As in such structure, that the cementite is formed as a result from making different sizes of bloom irons through direct-reduction process to iron artifact by hot forging below eutectoid temperature is regarded as air cooling and annealing when reheated.

As an enlarged picture of nonmetallic inclusions of iron artifact through SEM, Figure 2D analyzed the point a as EDS and the result is illustrated in Table 2. As the result of the analysis, it is a basic slag that contains $\mathrm{SiO}_{2}, \mathrm{CaO}, \mathrm{K}_{2} \mathrm{O}, \mathrm{Al}_{2} \mathrm{O}_{3}, \mathrm{P}_{2} \mathrm{O}_{5}$ and its maximum smelting temperature is estimated at $1,240^{\circ} \mathrm{C}$ and $\mathrm{P}_{2} \mathrm{O}_{5}$ does not seem to have been roasted. Moreover, it is defined that they used to charge liming materials such as shells or bones to furnace as flux to work looking at the ratio of $\mathrm{SiO}_{2}: \mathrm{CaO}: \mathrm{Al}_{2} \mathrm{O}_{3}$.

One iron axe produced by casting was excavated from 5 th and 10th site of house each in Daesung-ri, Gapyeong. The specimen of the iron axe excavated from the 10th site of house was collected from the same point as Figure 3A and observed to analyze the structure of these artifacts and they show similar aspects overall as a rough ferrite matrix structure as in Figure 3B although the entire microstructure of casting iron axe varies. The tiny pores in the microstructure are the ones that were formed upon casting and you can see corroded magnetite inside the pore wall. When casted, microstructure appears to be white cast iron or gray cast iron depending on cooling velocity as the structure of cast iron of $2-5 \% \mathrm{C}$ but looking at the $\mathrm{X}$-ray result, tiny holes have been formed on the ferrite structure of pure iron or casting artifacts that have a lot of casting pores in iron axes excavated from Daesung-ri. As an enlarged picture of left edge of the specimen, widmanstätten structure that precipitated to lath can be seen in Figure 3C. Widmanstätten, a rough ferrite structure on the left that is close to pure iron, on the right side of microstructure, seems to have fine structure as the edge is reheated through hot forging to $900^{\circ} \mathrm{C}$ near the point $\mathrm{A}_{3}$ after decarbonization and the layer cementite in pearlite is spheroidized. Considering these structures, a pore phenomenon inside, outside casting adhesive line and structure, it is regarded that carbon inside the cast iron reacted to oxygen, evaded as $\mathrm{CO}$ or $\mathrm{CO}_{2}$ gas and holes were formed due to the decarbonization in process of closed heating for long time after casting.

As an enlarged picture of the big nonmetallic inclusions on the top right of Figure 3C by SEM, in Figure 3D, the point a was analyzed by EDS and the result was summarized in Table 3 . According to the components found in Table 3 , the point a has a lot of $\mathrm{FeO}, \mathrm{SiO}_{2}$ and $\mathrm{P}_{2} \mathrm{O}_{5}$ and small amount of $\mathrm{CaO}, \mathrm{MnO}, \mathrm{MgO}$ which means less reduced wüstite is being formed on the fayalite and olivine basic slag, and $\mathrm{P}_{2} \mathrm{O}_{5}$ is found high as it is not roasted. In the result of analysis through EDS, when FAS, the major element, is substituted with ternary phase diagram, the maximum smelting temperature of the basic slag oxide is assumed to be about $1,390^{\circ} \mathrm{C}$.

The socket structure of iron axe excavated from the 5th site of house in Daesung-ri has tiny holes in rough ferrite grain on top and black pearlite is formed between relatively fine ferrite grains at the bottom as in Figure 4A, which is regarded as a structure that has been formed after cementite of white cast iron being reduced to pearlite due to not enough time upon decarbonization when
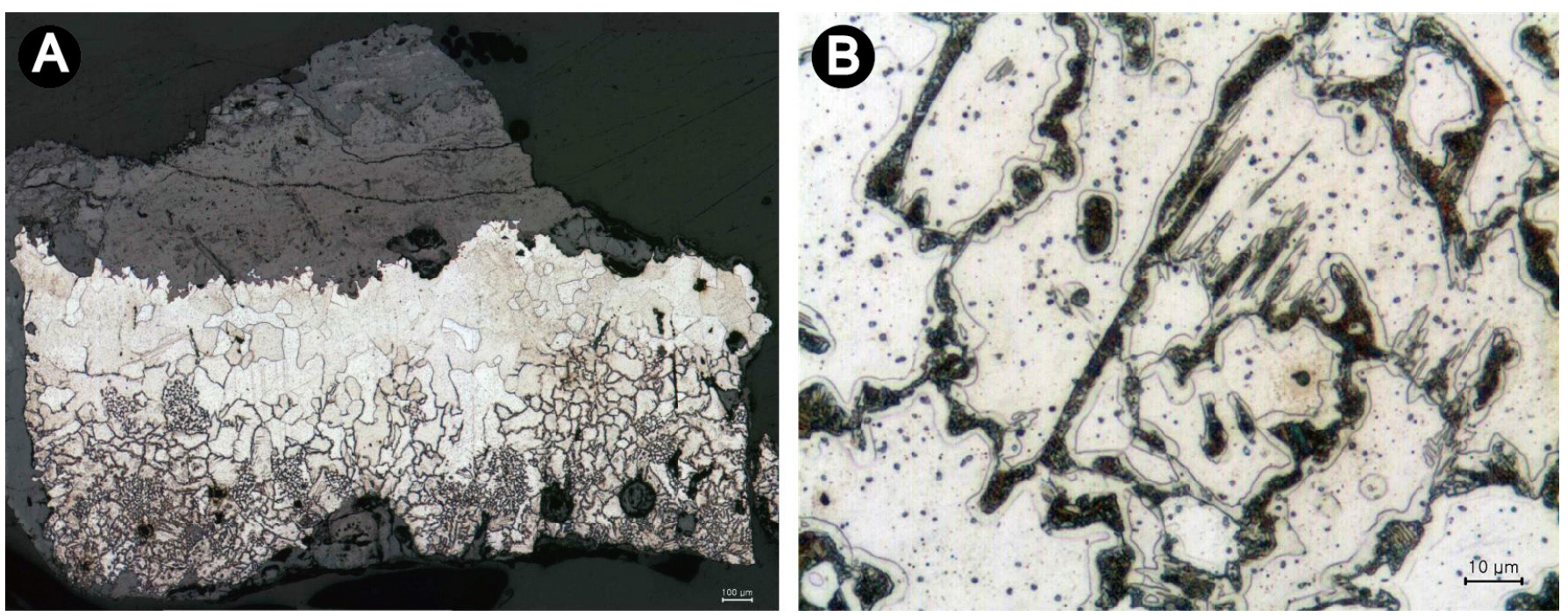

Figure 4. Microstructure of iron axe excavated from the $5^{\text {th }}$ site of house in Daesung-ri site (Yang and Kim, 2011). (A) Overall view of microstructure of an iron axe. (B) The lower section (left) of (A). 
cementite and ledeburite of white cast iron structure is decarbonized for long time. As an enlarged structure of bottom left in Figure 4A, you can observe holes formed near where carbon used to be after decarbonization in ferrite matrix in Figure 4B, and a line structure outside the ferrite grain is regarded as a line that has been formed when cementite and ledeburite were decarbonized from white cast iron structure and reduced and spread to ferrite (Yang and Kim, 2011).

\subsection{Iron objects from Yeongjong-do, Incheon}

As in Figure 5 and 6, I collected 1 iron sickle from the tip, 2

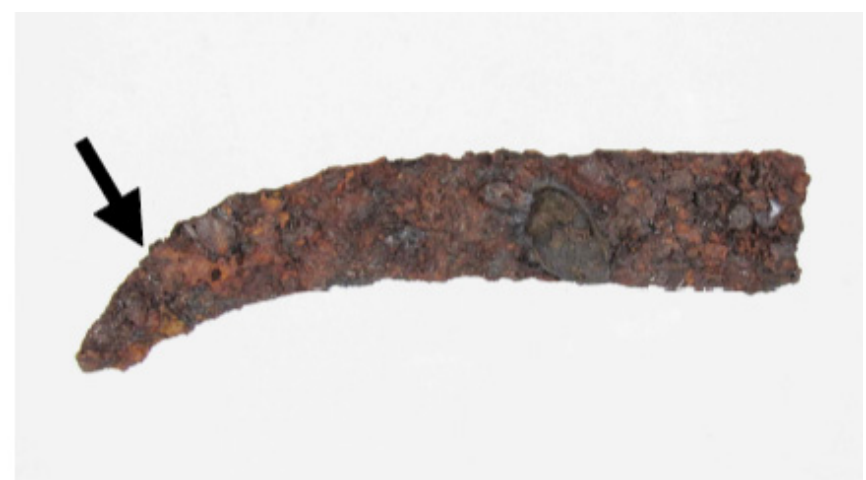

Figure 5. Sampling position (Kim, 2011). iron chisels from the edge and tail of iron chisel and sheel mound of the same area excavated from the layer that includes artifact in B area of Yeongjong-do site to analyze metallographically (Kim, 2011).

The result of the analysis on the structure of iron sickle excavated from sheel mound, the overall structure was similar and ferrite and pearlite were formed in matrix. As in Figure 7A, carbon on iron sickle tip is about $0.7 \%$, which is almost the same as that of eutectoid steel, considering the fact that martensite and troostite, microstructures, are observed together, it seems that martensite was formed first by quenching, reheated at $300-400^{\circ} \mathrm{C}$ and cooled in air. As in this structural aspect, it is regarded that

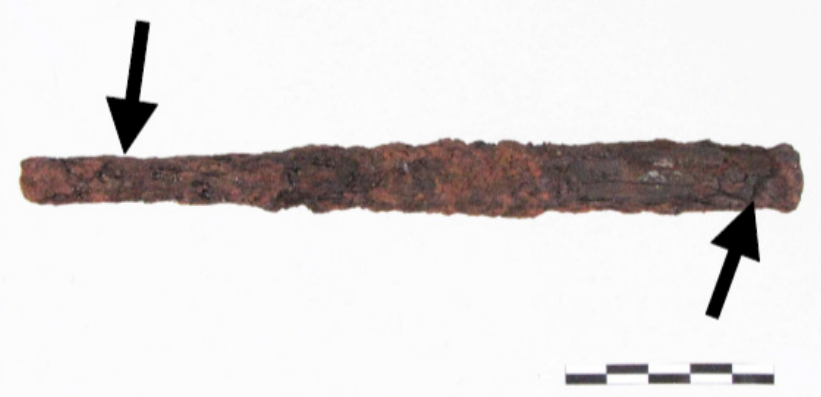

Figure 6. Sampling position (Kim, 2011).

Table 4. Analysis result of SEM-EDS in Figure 7B (wt \%) and temperature of ternary phase diagram $\left({ }^{\circ} \mathrm{C}\right)$.

\begin{tabular}{cccccccc|cc}
\hline Point & $\mathrm{MgO}$ & $\mathrm{Al}_{2} \mathrm{O}_{3}$ & $\mathrm{SiO}_{2}$ & $\mathrm{P}_{2} \mathrm{O}_{5}$ & $\mathrm{~K}_{2} \mathrm{O}$ & $\mathrm{CaO}$ & $\mathrm{FeO}$ & $\mathrm{FAS}$ & $\mathrm{FCS}$ \\
\hline 1 & 2.08 & 4.92 & 37.27 & 2.78 & 1.61 & 34.61 & 16.73 & 1,550 & 1,350 \\
2 & - & 1.55 & 10.08 & - & 1.36 & 13.89 & 73.12 & 1,100 & 1,290 \\
3 & 2.01 & 5.10 & 35.79 & 3.7 & 2.06 & 33.54 & 17.80 & 1,590 & 1,330 \\
4 & 1.91 & 3.55 & 29.52 & 2.51 & 1.18 & 24.78 & 36.55 & 1,300 & 1,150 \\
\hline
\end{tabular}
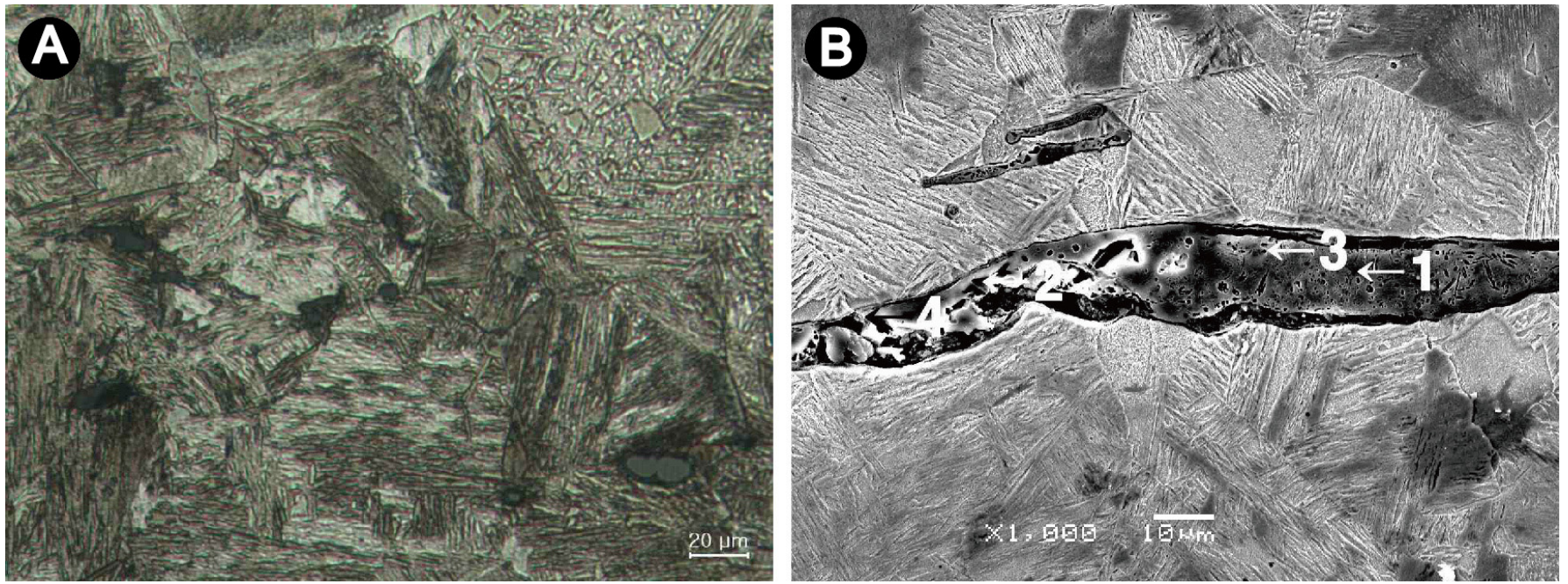

Figure 7. Microstructure of iron sickle excavated from sheel mound in B area of Yeongjong-do site (Kim, 2011). (A) Martensite located tip. (B) The SEM image of tip. 
they released martensite brittleness through softening that reheats it and relatively slowly cools in air after quenching in order to prevent the edge of iron sickle from break due to martensite.

Figure 7B is a picture of nonmetallic inclusions on the iron sickle tip taken with SEM, black part near nonmetallic inclusions is coagulated after nonmetallic inclusions are melted and the hole was formed by the difference between matrix structure and contraction rates or by wandering oxygen that is formed by

Table 5. Analysis result of SEM-EDS in Figure $8 \mathrm{C}(\mathrm{wt} \%)$ and temperature of ternary phase diagram $\left({ }^{\circ} \mathrm{C}\right)$.

\begin{tabular}{ccccccc|cc}
\hline Point & $\mathrm{MgO}$ & $\mathrm{Al}_{2} \mathrm{O}_{3}$ & $\mathrm{SiO}_{2}$ & $\mathrm{~K}_{2} \mathrm{O}$ & $\mathrm{CaO}$ & $\mathrm{FeO}$ & $\mathrm{FAS}$ & $\mathrm{FCS}$ \\
\hline 1 & 1.52 & 4.53 & 30.06 & 4.12 & 21.32 & 38.45 & 1,280 & 1,500 \\
2 & 1.48 & 3.41 & 20.14 & 2.29 & 12.45 & 60.23 & 1,150 & 1,250 \\
3 & 1.35 & 0.46 & 0.79 & - & - & 97.40 & 1,050 & 1,250 \\
\hline
\end{tabular}

Table 6. Analysis result of SEM-EDS in Figure $8 \mathrm{D}(\mathrm{wt} \%)$ and temperature of ternary phase diagram $\left({ }^{\circ} \mathrm{C}\right)$.

\begin{tabular}{cccccccc|cc}
\hline Point & $\mathrm{MgO}$ & $\mathrm{Al}_{2} \mathrm{O}_{3}$ & $\mathrm{SiO}_{2}$ & $\mathrm{P}_{2} \mathrm{O}_{5}$ & $\mathrm{~K}_{2} \mathrm{O}$ & $\mathrm{CaO}$ & $\mathrm{FeO}$ & $\mathrm{FAS}$ & $\mathrm{FCS}$ \\
\hline 1 & 1.37 & 3.85 & 36.57 & 2.74 & 3.22 & 16.85 & 35.40 & 1,430 & 1,150 \\
2 & - & 1.53 & 11.39 & - & 0.65 & 3.02 & 83.41 & 1,100 & 1,320 \\
3 & - & 1.54 & 14.03 & - & 1.08 & 5.36 & 77.99 & 1,110 & 1,300 \\
\hline
\end{tabular}
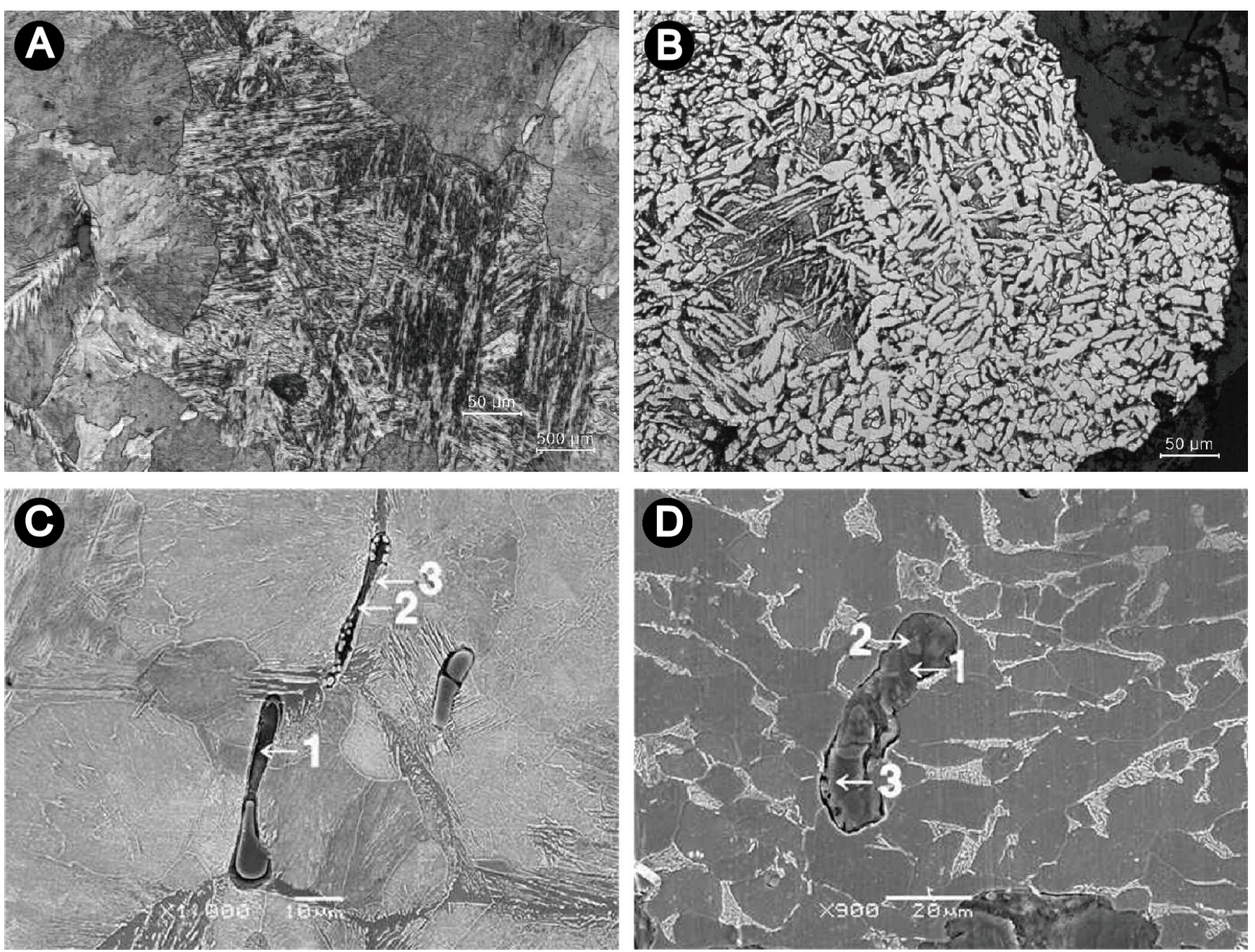

Figure 8. Microstructure of iron chisel excavated from the Yeongjong-do site (Kim, 2011). (A) Martensite located edge. (B) Widmanstätten located back. (C) The SEM image of edge. (D) The SEM image of back. 
reduction of $\mathrm{FeO}$ in nonmetallic inclusions. The marked part is what I analyzed through EDS and Table 4 is the result of the analysis. In Table 4, all parts except the point 2 are basic slag mixed with fayalite and olivine, seeing that $\mathrm{SiO}_{2}$ and $\mathrm{Al}_{2} \mathrm{O}_{3}$ are very small in the point 2 , crystallization temperature to wüstite seems to be $1,100^{\circ} \mathrm{C}$ and the maximum smelting temperature of basic slag seems to be $1,350^{\circ} \mathrm{C}$. In addition, seeing that the construction rates of all four points are similar, compounds of calcium that have a lot of $\mathrm{Ca}$ seems to have been put as a flux on purpose.

As in Figure 6, I collected specimen from the edge and tail of iron chisel and analyzed that martensite, a quenching structure formed upon quenching after carburizing, was observed on the iron chisel edge as in Figure 8A and small amount of ferrite was formed on the specimen matrix at the iron chisel tail as in Figure 8B. Seeing that carbon at the tail is below $0.3 \%$ and widmanstätten structure was formed after partially being overheated and cooled in air, it seems that the point $\mathrm{A}_{3}$ reached around $900^{\circ} \mathrm{C}$. As such, it was defined that heat treatment was partially done on the part for quenching the iron chisel blade.

As in Table 5 that analyzed the marked part in Figure 8C, seeing that there were a lot of $\mathrm{SiO}_{2}$ and $\mathrm{MgO}$ was found, it seems that the basic slag of wüstite formed on fayalite and olivine had the maximum smelting temperature of $1,250^{\circ} \mathrm{C}$ and the bead type wüstite crystallization temperature of the point 3 is about $1,050^{\circ} \mathrm{C}$. Table 6 is the result of the analysis from the position of Figure 8D, which is a basic slag that has less reduced white wüstite on the background of fayalite and olivine, and the oxide of this part seems to have the maximum smelting temperature of around $1,320^{\circ} \mathrm{C}$. Also, seeing that $\mathrm{CaO}$ is relatively higher than $\mathrm{SiO}_{2}$, it seems that compounds of calcium such as shells were added as a flux upon smelting.
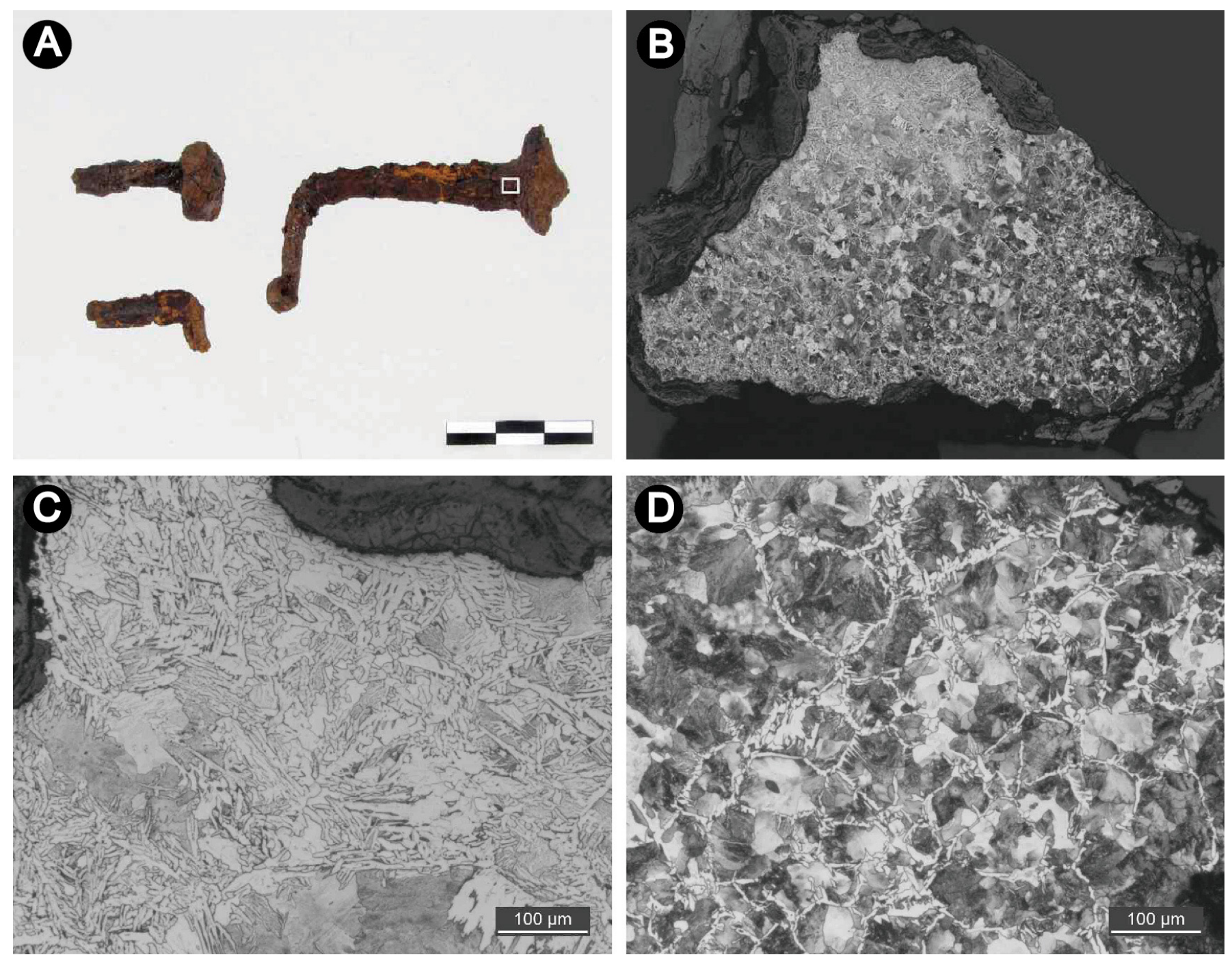

Figure 9. Microstructure of nail excavated from Garak $1^{\text {st }}$ lake basin. (A) Sampling position. (B) Overall view microstructure of sample of nail. (C) Widmanstätten located upper section of sample. (D) Carburized network cementite. 
Table 7. Analysis result of SEM-EDS in Figure 10 (wt \%) and temperature of ternary phase diagram $\left({ }^{\circ} \mathrm{C}\right)$.

\begin{tabular}{cccccccc|cc}
\hline Point & $\mathrm{Na}_{2} \mathrm{O}$ & $\mathrm{Al}_{2} \mathrm{O}_{3}$ & $\mathrm{SiO}_{2}$ & $\mathrm{P}_{2} \mathrm{O}_{5}$ & $\mathrm{~K}_{2} \mathrm{O}$ & $\mathrm{CaO}$ & $\mathrm{FeO}$ & FAS & FCS \\
\hline $\mathrm{A}$ & 0.54 & 2.94 & 20.26 & 1.07 & 1.47 & 7.94 & 65.78 & 1,150 & 1,250 \\
\hline
\end{tabular}

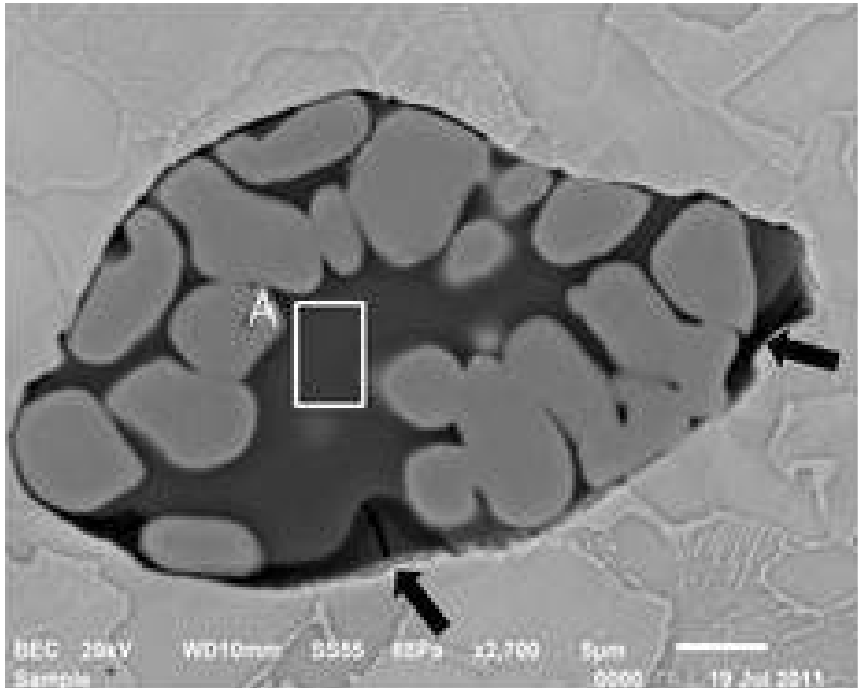

Figure 10. The SEM image of nail.

\subsection{Iron objects from Garak-dong, Seoul}

In the site of Garak-dong, I collected and observed specimen from the same position as Figure 9A in order to analyze the structure of nails excavated from Garak 1st lake basin. As in Figure 9B, what was observed was widmanstätten structure, ferrite structure of lath cooled in air after being overheated hypo-eutectoid steel, on top and under that part, carburizing structure formed overall. As in the enlarged picture of the top part of Figure 9B, a widmanstätten structure that is closer to pure iron due to incomplete carburizing compared to the bottom is observed, and in Figure 9D which is an enlarged picture of bottom right of Figure 9B, ferrite of fine lath becomes pearlite in widmanstätten structure of carburized lath and widmanstätten structure coexists in network form as rough ferrite does not be carburized. It seems that the hardness in some structures of white many-sided traits is $301.5 \sim 309.0 \mathrm{Hv}$, which is higher than that of normal pearlite structure, as the amount of cementite got piled up in pearlite of layer upon carburizing.

Figure 10 illustrates the SEM layer of nonmetallic inclusions of lower top that has below $0.2 \% \mathrm{C}$ of carbon in Figure 9B, the result of the analysis was summarized in Table 7. Light gray bead type part in Figure 10 is wüstite, the indicator microstructure of iron artifact formed by the method of reduction iron manufacture, and darker gray part of the point $\mathrm{A}$ is a glassy basic slag which has incompletely reduced $\mathrm{FeO}$ as the major element and small amount of $\mathrm{SiO}_{2}, \mathrm{CaO}, \mathrm{K}_{2} \mathrm{O}, \mathrm{Al}_{2} \mathrm{O}_{3}$ in it and its maximum smelting temperature seems to be about $1,250^{\circ} \mathrm{C}$. The black arrow seems to be either the hole formed when smelting nonmetallic inclusions were coagulated and contracted in process of nails being hot forged or the volume of oxygen left from $\mathrm{FeO}$ when wüstite in the glassy nonmetallic inclusions were reduced and transferred to microstructure.

Figure $11 \mathrm{~A}$ is the whole structured specimen that was collected and observed from the central part of clamp excavated from the 2nd lake basin in Garak, and it is closer to pure iron below $0.05 \% \mathrm{C}$. Figure 11B is an enlarged picture of the bottom part of the specimen, pearlite is observed formed on the grain boundary of ferrite as small amount of carbon increased upon carburizing due to hot working. In addition, seeing that black bead type of nonmetallic inclusions are scattered throughout the specimen in Figure 11B, it is regarded that slags are not removed and mixed as not enough forging work is done for sponge-iron or bloom iron reduced by direct-reduction process. In this structure, clamp was made without any special work or heat treatment from bloom iron formed by solid reduction at low temperature on the surface in process of making clamp by forging. Seeing that the structures of clamps excavated from the site in Garak-dong are all overheated widmanstätten ones and partially carburized, carburizing seems to have been naturally done in process of hot forging in a furnace.

As an SEM of nonmetallic inclusions of clamp excavated from the 2nd lake in Garang-dong, Figure 11C summarizes the result of the EDS analysis on marked part. According to the result of the analysis that relatively small amount of $\mathrm{SiO}_{2}$ and high $\mathrm{FeO}$ in four parts, it is estimated that incompletely reduced $\mathrm{Fe}$ is the main element and the maximum smelting temperature of a glassy basic slag that has small amount of $\mathrm{P}_{2} \mathrm{O}_{5}, \mathrm{CaO}, \mathrm{K}_{2} \mathrm{O}, \mathrm{Al}_{2} \mathrm{O}_{3}$ is 1,31 $0^{\circ} \mathrm{C}$, and light gray $\mathrm{B}$ and $\mathrm{D}$ has bead type wüstite that has $\mathrm{FeO}$ as the main element and the crystallization temperature of 1,05 $0^{\circ} \mathrm{C}$. Seeing that $\mathrm{P}_{2} \mathrm{O}_{5}$ is analyzed to be high in this basic slag, it is assumed that raw stone was charged to furnace without roasting. An analysis of a clamp excavated from the Garak 1st Lake in the site of Garang-dong showed that its structure is similar to nonmetallic inclusions of clamp excavated from the Garak 2nd Lake, and a basic slag that has wüstite with incompletely reduced $\mathrm{FeO}$ as the major element and small amount of $\mathrm{SiO}_{2}, \mathrm{P}_{2} \mathrm{O}_{5}, \mathrm{CaO}$, $\mathrm{K}_{2} \mathrm{O}$ was found.

I collected specimen from the back edge, edge and socket and observed them as in Figure 12 to analyze structure of iron knife excavated from the Garak 2nd Lake, and found that back edge and edge had overall similar microstructure with minor differences. Also, martensite, a structure for quenching, was formed in general as in Figure 14A, pearlite colony was formed 
in part as in Figure 14B, and dark gray nonmetallic inclusions that looked like glassy was mixed. Pearlite colony formed on the martensite of iron knife was resulted from the quenching process of hypo-eutectoid steel below $0.6 \%$, such structure was formed by quenching at higher temperature than critical temperature of iron knife and by cooling at lower temperature than critical cooling rate and was spit transformation. As a microstructure of specimen on socket part of iron knife, Figure 14C has small amount of pearlite between rough ferrites and there are great and small nonmetallic inclusions scattered in part. Thus, seeing that there is a lot of carbon in the edge of iron knife and that there is martensite on the edge and back edge while no martensite was found on socket, it is regarded that the edge was quenched in furnace after carburizing and partial heat treatment was done for sockets not quenched.

As enlarged by SEM, Figure 14D is a picture of nonmetallic inclusions of specimen on the back edge of iron knife excavated from the Garak 2nd Lake, and Table 9 is the result of the analysis on nonmetallic inclusions by EDS. As in Table 9, the maximum smelting temperature of a basic slag that has $\mathrm{FeO}$ and $\mathrm{SiO}_{2}$ as the major elements is estimated at $1,250^{\circ} \mathrm{C}$. In addition, although it has over $5 \%$ of $\mathrm{CaO}$, iron is reduced and $\mathrm{CaO}$ looks like a lot and it has relatively smaller amount than $\mathrm{SiO}_{2}$, so it is difficult to say that a component whose major element is $\mathrm{Ca}$ was put as a flux on purpose.

As in Figure 13, I collected specimen of iron spear from fleet,

Table 8. Analysis result of SEM-EDS in Figure $11 \mathrm{C}(\mathrm{wt} \%)$ and temperature of ternary phase diagram $\left({ }^{\circ} \mathrm{C}\right)$.

\begin{tabular}{cccccccccccc}
\hline Point & $\mathrm{MgO}$ & $\mathrm{Al}_{2} \mathrm{O}_{3}$ & $\mathrm{SiO}_{2}$ & $\mathrm{P}_{2} \mathrm{O}_{5}$ & $\mathrm{~K}_{2} \mathrm{O}$ & $\mathrm{CaO}$ & $\mathrm{MnO}$ & $\mathrm{FeO}$ & $\mathrm{FAS}$ & FCS \\
\hline $\mathrm{A}$ & - & - & 11.91 & 3.30 & - & 0.46 & 1.00 & 83.09 & - & 1,300 \\
$\mathrm{~B}$ & - & - & 7.88 & 2.11 & - & 0.27 & 0.89 & 88.62 & - & 1,350 \\
$\mathrm{C}$ & 0.36 & 0.66 & 10.98 & 6.70 & 0.31 & 1.65 & 0.46 & 78.59 & 1,050 & 1,310 \\
$\mathrm{D}$ & - & 0.46 & 6.87 & 4.36 & 0.20 & 1.20 & 0.40 & 86.20 & 1,050 & 1,360 \\
\hline
\end{tabular}
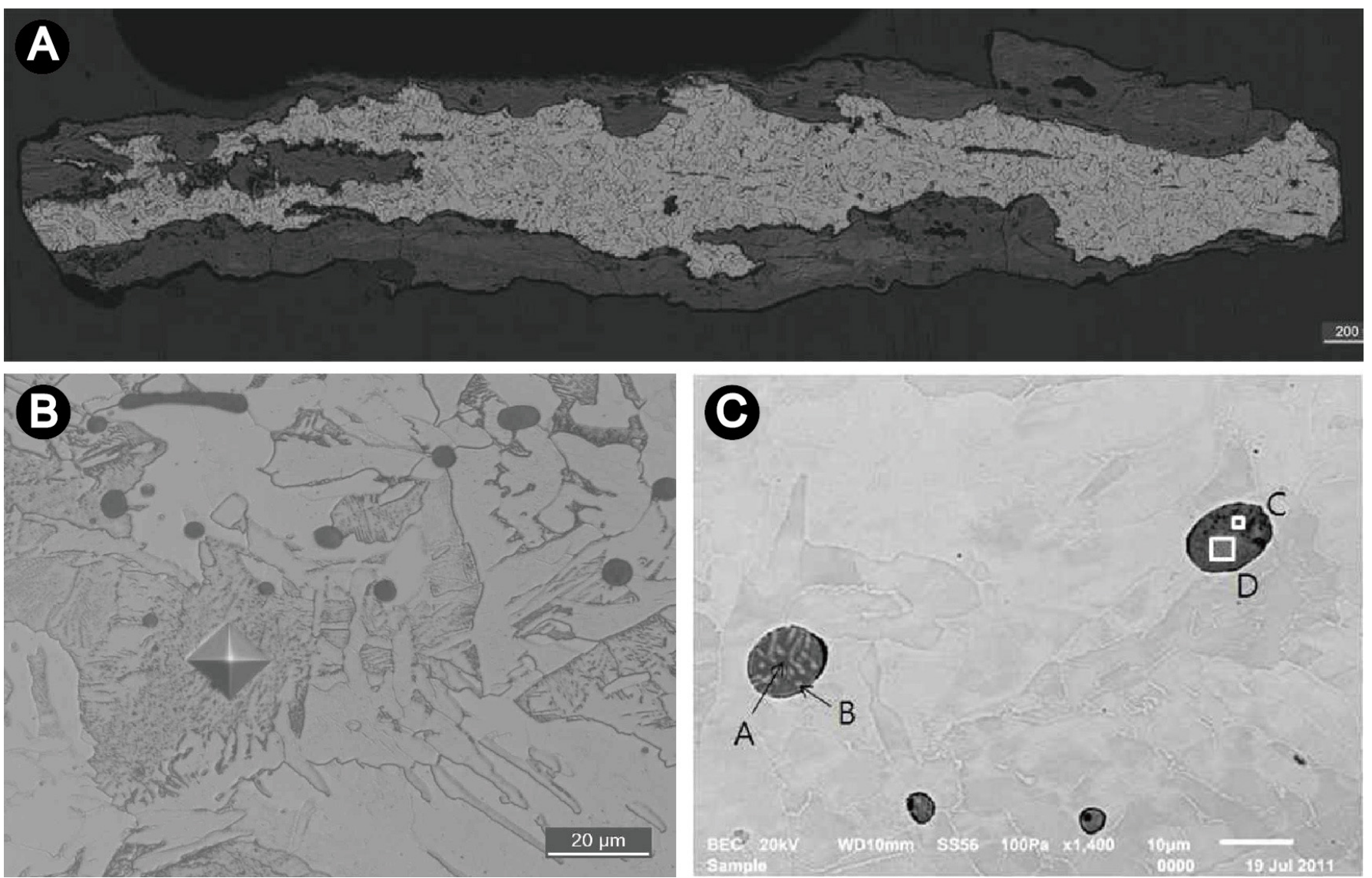

Figure 11. Microstructure of clamp excavated from the $2^{\text {nd }}$ lake basin in Garak site. (A) Overall view of microstructure of sample of clamp. (B) Nonmetallic inclusion of the left side. (C) The SEM image of nonmetallic inclusion. 
edge and the center of the body and observed them. Although the whole structures of all specimens vary, it is uneven as overheated structures of widmanstätten and pearlite are mixed. As in Figure $15 \mathrm{~A}$, the whole structure of edge specimen is relatively even, the
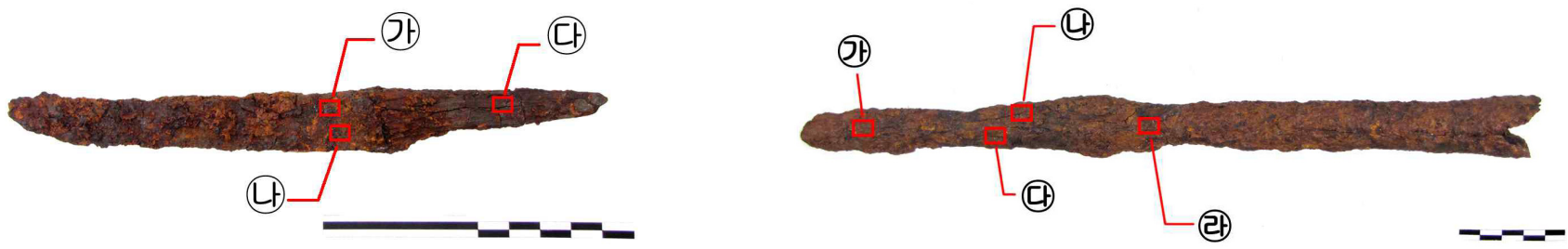

Figure 12. Sampling position.

Figure 13. Sampling position.

Table 9. Analysis result of SEM-EDS in Figure 14D $(\mathrm{wt} \%)$ and temperature of ternary phase diagram $\left({ }^{\circ} \mathrm{C}\right)$.

\begin{tabular}{cccccccc|cc}
\hline Point & $\mathrm{MgO}$ & $\mathrm{Al}_{2} \mathrm{O}_{3}$ & $\mathrm{SiO}_{2}$ & $\mathrm{~K}_{2} \mathrm{O}$ & $\mathrm{CaO}$ & $\mathrm{TiO}_{2}$ & $\mathrm{FeO}$ & $\mathrm{FAS}$ & $\mathrm{FCS}$ \\
\hline $\mathrm{A}$ & 1.72 & 1.75 & 42.14 & 2.58 & 6.78 & 0.26 & 44.78 & 1,500 & 1,250 \\
$\mathrm{~B}$ & 1.70 & 2.00 & 41.40 & 2.52 & 6.89 & 0.38 & 45.11 & 1,450 & 1,180 \\
\hline
\end{tabular}
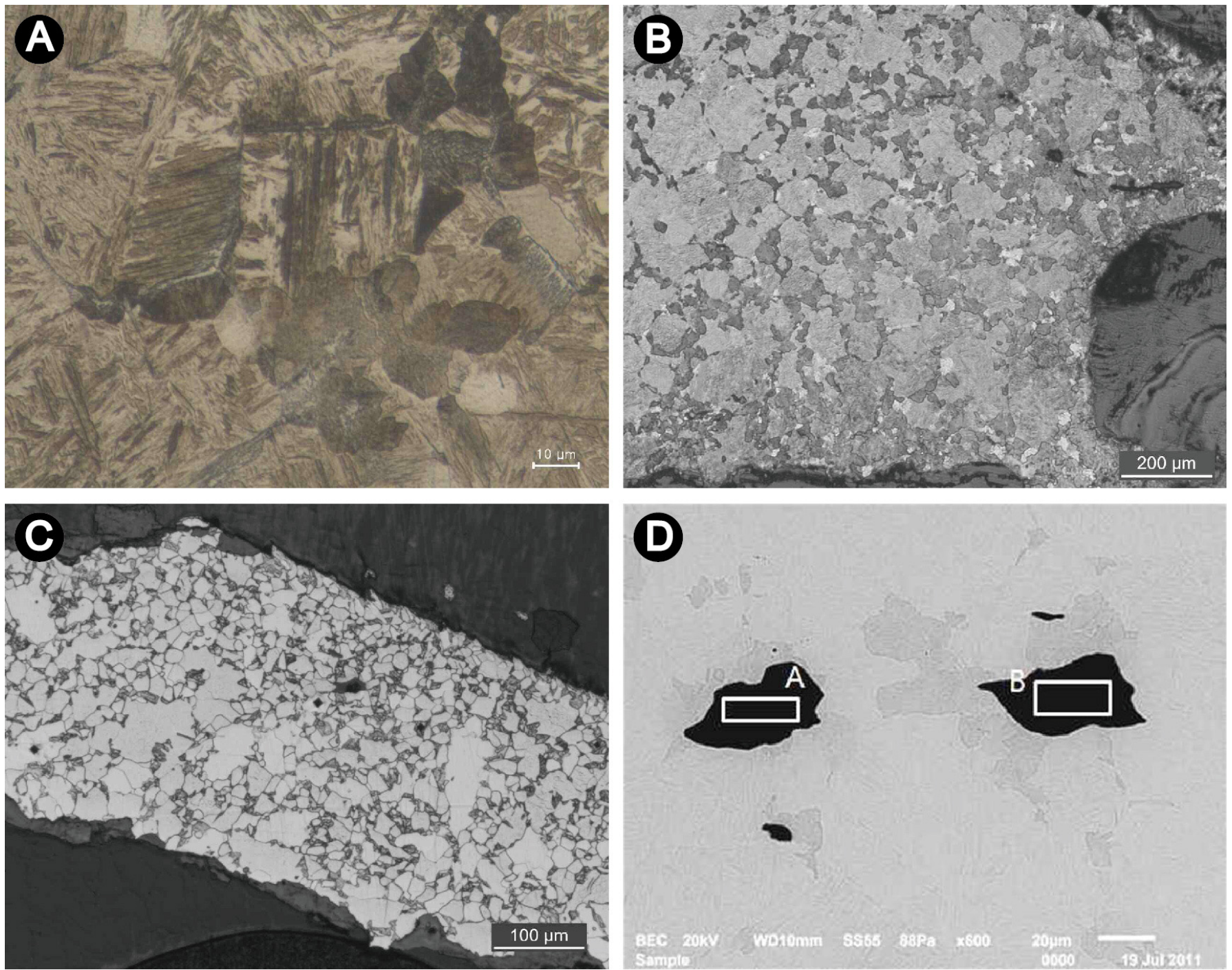

Figure 14. Microstructure of iron knife excavated from the Garak $2^{\text {nd }}$ lake. (A) Martensite located edge. (B) Pearlite colony located back edge. (C) Ferrite of iron knife socket. (D) The SEM image of the back edge of iron knife. 
amount of carbon is close to $0.7 \%$, of eutectoid steel, and network widmanstätten is formed on the matrix of pearlite. Figure 15B is a microstructure of body centered specimen which is similar to edge one, glassy nonmetallic inclusions are mixed.

Figure 15C analyzed nonmetallic inclusions of specimen of iron spear tip excavated from Garak-dong on SEM by EDS, and its results are summarized in Table 10. A in Table 10 is a fayalite basic slag where small amount of incompletely reduced $\mathrm{SiO}_{2}$, $\mathrm{Al}_{2} \mathrm{O}_{3}$ and $\mathrm{CaO}, \mathrm{K}_{2} \mathrm{O}$ are in solid solution whose maximum smelting temperature is $1,150^{\circ} \mathrm{C}$ and $\mathrm{B}$ is less incompletely reduced wüstite whose crystallization temperature is estimated to be $1,050^{\circ} \mathrm{C}$.

Table 10. Analysis result of SEM-EDS in Figure $15 \mathrm{C}(\mathrm{wt} \%)$ and temperature of ternary phase diagram $\left({ }^{\circ} \mathrm{C}\right)$.

\begin{tabular}{cccccccc|cc}
\hline Point & $\mathrm{Na}_{2} \mathrm{O}$ & $\mathrm{MgO}$ & $\mathrm{Al}_{2} \mathrm{O}_{3}$ & $\mathrm{SiO}_{2}$ & $\mathrm{~K}_{2} \mathrm{O}$ & $\mathrm{CaO}$ & $\mathrm{FeO}$ & $\mathrm{FAS}$ & $\mathrm{FCS}$ \\
\hline $\mathrm{A}$ & 0.39 & 0.61 & 3.87 & 17.49 & 0.93 & 0.99 & 75.72 & 1,150 & 1,250 \\
$\mathrm{~B}$ & - & - & 1.26 & 4.05 & - & - & 94.36 & 1,050 & - \\
\hline
\end{tabular}

Table 11. Analysis result of SEM-EDS in Figure 15D (wt \%) and temperature of ternary phase diagram $\left({ }^{\circ} \mathrm{C}\right)$.

\begin{tabular}{ccccccccc|cc}
\hline Point & $\mathrm{Na}_{2} \mathrm{O}$ & $\mathrm{MgO}$ & $\mathrm{Al}_{2} \mathrm{O}_{3}$ & $\mathrm{SiO}_{2}$ & $\mathrm{P}_{2} \mathrm{O}_{5}$ & $\mathrm{~K}_{2} \mathrm{O}$ & $\mathrm{CaO}$ & $\mathrm{FeO}$ & $\mathrm{FAS}$ & $\mathrm{FCS}$ \\
\hline $\mathrm{A}$ & - & 1.37 & 0.70 & 18.17 & - & - & 0.45 & 79.31 & 1,050 & 1,250 \\
B & 1.24 & - & 8.97 & 21.86 & 1.25 & 3.52 & 3.38 & 59.78 & 1,220 & 1,200 \\
\hline
\end{tabular}
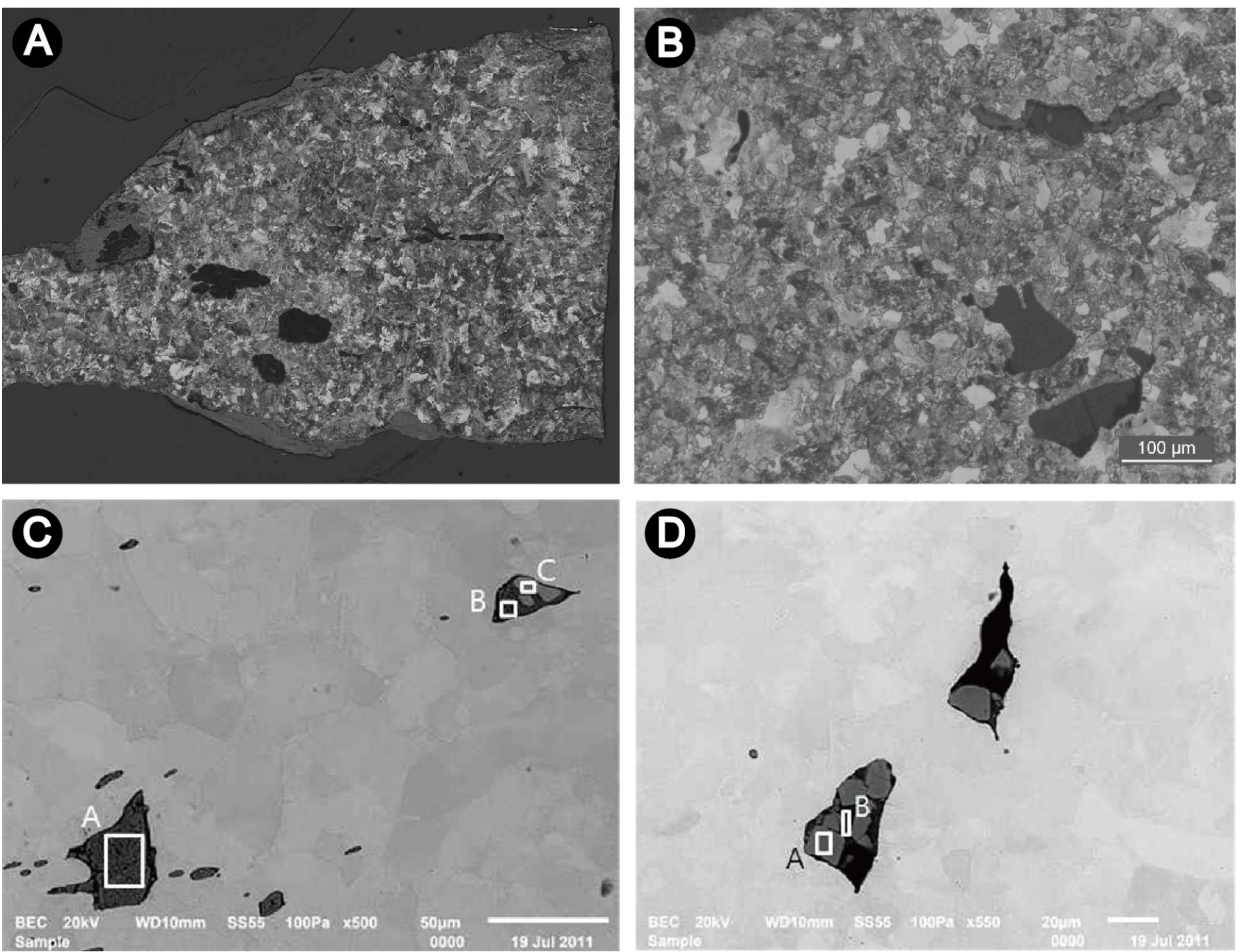

Figure 15. Microstructure of iron spear excavated from Garak site. (A) Overall view of microstructure of edge of iron spear. (B) Pearlite located the body of iron spear. (C) Nonmetallic inclusion of fleet of iron spear. (D) Nonmetallic inclusion of edge of iron spear. 


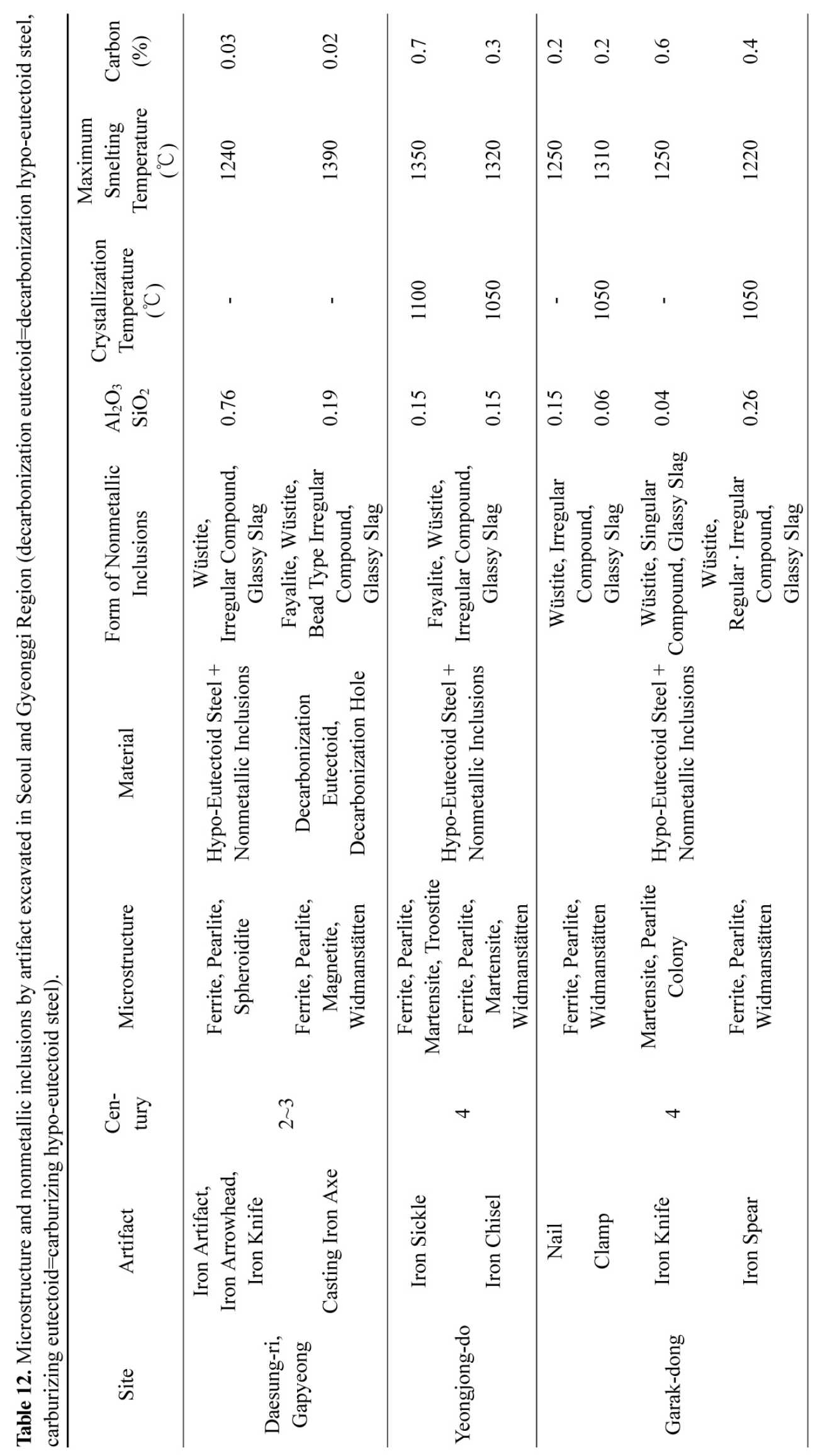


Figure 15D analyzed nonmetallic inclusions of edge specimen on the position marked as SEM layer by EDS and its result of the analysis is summarized in Table 11. The light point $\mathrm{A}$ is incompletely reduced wüstite whose crystallization temperature is $1,050^{\circ} \mathrm{C}$ and the black point $\mathrm{B}$ is fayalite basic slag whose maximum smelting temperature seems to be $1,220^{\circ} \mathrm{C}$.

\subsection{Summary and discussion}

Table 12 summarizes analyzed structure and nonmetallic inclusions of iron artifact excavated from Seoul and Gyeonggi area and it seems that partial heat treatment was done depending on the purpose of artifact or on occasion demands. Seeing that the content of $\mathrm{Al}_{2} \mathrm{O}_{3}$ is lower than $\mathrm{SiO}_{2}$ in iron ore, it is regarded that they worked with magnetite. Also, what is noteworthy is that the structure of casting iron axe excavated from Daesung-ri, Gapyeong was decarbonized after casting of iron axe, supplemented the weakness of casting artifact that has strong brittleness and was found to be cast iron decarbonization steel with tenacity.

The result of EDS analysis showed that as wüstite was crystallized a lot, most of them except solid decarbonized iron axe excavated in Daesung-ri was made by direct-reduction process. The crystallization temperature of such wüstite was estimated to be around $1,050^{\circ} \mathrm{C}$ and $\mathrm{CaO}, \mathrm{Al}_{2} \mathrm{O}_{3}, \mathrm{~K}_{2} \mathrm{O}, \mathrm{MgO}, \mathrm{P}_{2} \mathrm{O}_{5}$ were in solid solution of glassy slag in fayalite and olivine of nonmetallic inclusions, its solidification temperature was about $1,250^{\circ} \mathrm{C}$ and varied depending on the content of $\mathrm{FeO}$ and $\mathrm{CaO}, \mathrm{Al}_{2} \mathrm{O}_{3}$.

\section{CONCLUSION}

I researched microstructure of iron artifact excavated from Han River basin in Proto-Three Kingdoms, measured microhardness, analyzed nonmetallic inclusions mixed in microstructure and reinterpreted the results as ternary phase diagram to study work temperature. In addition, I acquired following results of steel manufacture that uses heat treatment and manufacturing technology by metallographic interpretation.

Seeing that the portion of iron ore is $\mathrm{Al}_{2} \mathrm{O}_{3} / \mathrm{SiO}_{2}$ regardless of region and age and the content of $\mathrm{SiO}_{2}$ is high and $\mathrm{Al}_{2} \mathrm{O}_{3}$ is relatively low in iron artifacts of Han River basin in Proto-Three Kingdoms, it is assumed that they worked with magnetite. Also, seeing that wüstite, indicator structure of iron artifact that was formed by direct-reduction process, is crystallized in nonmetallic inclusions, it is regarded that bloom iron and sponge-iron were made through direct-reduction process and transformed to iron artifacts.

Carburizing steel that carburizes by $\mathrm{CO}, \mathrm{CO}_{2}$ gas that comes from charcoal when forge welding bloom iron that is close to pure iron is the steel manufacturing method, seeing that partial heat treatment was done on artifacts depending on the purpose of artifacts as in iron chisel excavated in Yeongjong-do or iron knife excavated in Garak-dong, I was able to find the technological perception of iron artifact manufacturers in Han River basin in Proto-Three Kingdoms. Seeing that artifacts with blade were carburized, quenched and heat treated, it is judged that such heat treatment was commonly used in Han River basin in the 3rd century.

It was found that wüstite was crystallized below the temperature of $1,050^{\circ} \mathrm{C}$ in below $1 \%$ of $\mathrm{Al}_{2} \mathrm{O}_{3}$ and considering the ternary phase diagram of glassy nonmetallic inclusions, it is assumed that iron manufacture work was done at the temperature of around $1,250^{\circ} \mathrm{C}$. With $1,400^{\circ} \mathrm{C}$ of the maximum smelting temperature of casting iron axe excavated in Daesung-ri, assuming its temperature in $\mathrm{Fe}-\mathrm{C}$ phase diagram, it was regarded as decarburized cast iron in which casting was done by hypoeutectic cast iron around $2.3 \% \mathrm{C}$, decarbonized in solid state, reduced to steel that is close to pure iron and improved brittleness of cast iron.

Structure portions of $\mathrm{CaO}$ and $\mathrm{SiO}_{2}$ of both the two artifacts from Yeongjong-do were similar which was different from that mixed in iron ore, and it is judged that calcareous elements such as shells with high content of $\mathrm{Ca}$ were put as a flux on purpose. Moreover, seeing that $\mathrm{P}_{2} \mathrm{O}_{5}$ is high in sites, it is assumed that unroasted iron ore was charged to furnace.

Although it was meaningful to research iron manufacture and manufacturing technology of iron artifacts in Han River basin during the Proto-Three Kingdoms through this study, I think the result cannot represent the era and region as there were not enough artifacts that are difficult to collect uncorroded specimen for analyzing the number of sites. However, it is considered that the outcome of this study will contribute to more research on the differences and similarities of iron manufacturing technology system in era and region of Han River basin, and I am confident that if such researches are done a lot, it will be important data to define the development of ancient iron manufacturing technologies.

\section{REFERENCE}

Engell, H.J., 1991, In: Shim, J.D. and Ban, B.C. (eds), Slags in Metallurgy. Daegwang Pub., Seoul, p.235.

Kim, J.G., Kim, K.Y. and Park, H.W., 1999, Metallography. Gold Publish Co., Seoul, p.203.

Kim, S.K., 2011, Incheon Unnam-dong Shell Mound. Korea Institute for Archaeology \& Environment, p.324 327.

Kim, W.N., 1986, Hanguk Gogohak Gaeseol, Introduction to Korean Archaeology. Iljisa, p.101 103.

Lee, Y.B., Park, H.C. and Oh, K.D., 2001, Phase Equilibrium Diagram in Ceramics. Dasung Pub., Seoul, p.176.

Yang, S.W. and Kim, S.K., 2011, Gapyeong Daeseong-ri Site П I. Gyeore Institute of Cultural Heritage, p.510 526. 